\title{
CORRESPONDENCE
}

Violence and mental illness

J L Reed, FRCPSYCH; S E Josse, FRCGP. . . . 249

Treatment of oesophageal cancer

I Viswanath, MRCP, and A N Hamlyn, MRCP;

K C McKeown, FRCS . . . . . . . . . . . 249

Video as a teaching aid

S Reith, FRCP, and others; R F Gledhill, MD 250

Uterine prolapse and urinary tract obstruction

B H Valentine, MrCog; G S Rai, MD, and

P Murphy, MRCP................ 250

The doctor and the child with learning problems

Anne Bolton, FRCPSYCH; T Stapleton, FRCl ;

Loretta Light, MRCS; A J Harbott, FRCPSYCH;

G J R Richardson, MRCPSYCH . . . . . . . 251

Oral contraceptives, pregnancy, and

endogenous oestrogen in gall stone

disease

M C Bateson, MD; R K R Scragg, $M B$, and

A J McMichael, MB ............. 252
Prescribing the pill to girls under 16

J N O'Neill, MRCGP.............. 252

Paunches and the prediction of coronary heart disease

D J Evans, MRCP, and A H Kissebah, MD. 252

Acyclovir for cytomegalovirus infection

P Selby, MD, and others............ 253

Economic efficiency in the NHS

R J Jarrett, FFCM; R S Morton, FRCPE. . . 253

Autoimmune thyroid disease and pregnancy

J How, MRCP, and others.

Switching from private to NHS treatment

V B Whittaker, FRCP; E B Lewis, FFARCS. . 254

Meningococcal septicaemia treated with combined plasmapheresis and leucapheresis or with blood exchange

R S Pedersen, MD, and others; B Bjorvatn,

$M D$, and others.............. 254
The dangers of drycleaning

J R Bennett, FRCP; H K Wilson, PHD, and

D Gompertz, FRCPATH............ 255

Instant age-sex register

L D Ritchie, MFCM, and D R Ferguson,

MRCGP ................... 255

Failure of comprehension in the

National Health Service

C G F Munton, FRCS, and others....... 255

Points Interactions with miconazole (J Descotes, and others); Endoscopic jejunal biopsy with the Crosby capsule (K F R Schiller); Epilepsy and the law (J Gunn); Outcome of pregnancies associated with raised serum and normal amniotic fluid $\alpha$-fetoprotein concentrations (W E Mackenzie); Hospital staffing structure (C J C Roberts); The GMC should be more concerned with the postgraduate rather than the primary qualification of overseas graduates ( $M$ Shaukat Ali); Mutiny over Bounty ? (Jane Robertson).......... 256

We may shorten letters to the editor unless the authors specifically state that we may not. This is so that we can offer our readers as wide a selection of letters as possible. We receive so many letters each week that we have to omit some of them. Letters must be typed with double spacing between lines and must be signed personally by all their authors, who should include their degrees. Letters critical of a paper may be sent to the authors of the paper so that their reply may appear in the same issue.

Correspondents should present their references in the Vancouver style (see examples in these columns). In particular, the names and initials of all authors must be given unless there are more than six, when only the first three should be given, followed by et al; and the first and last page numbers of articles and chapters should be included.

\section{Violence and mental illness}

SIR,-Dr Malcolm Weller (7 July, p 2) is right to condemn neglect of mental illness by successive governments. In the now to be expected criticism of community care, however, he misses two important points. Firstly, the change of policy being argued is not one of hospital care versus community care but of the relative merits of distant large mental hospitals and smaller local units with adequate community support. Goldberg's studies in south Manchester have shown that local services are more effective in treatment and are preferred by both patients and their families to distant mental hospitals. ${ }^{12}$

The second point is a practical one. Most cases of "community neglect" originate with patients being discharged from large mental illness hospitals into inadequate community provision without the responsible hospital consultant paying any adequate attention to the nature of the care to which his patient is returning. I am sure that $\mathrm{Dr}$ Weller will agree that a consultant's responsibility does not stop at the gates of a mental hospital.

Department of Psychological

J L REED Medicine,

Hackney Hospital

' Glass N, Goldberg OP. Cost benefit analysis and the valuation of psychiatric services. Psychol Med 1977, 7:701-7.

- Jones R, Goldberg OP, Hughes B. A comparison of two different services treating schizophrenia : a cost-
SIR,-I found the two articles by Dr Pamela J Taylor and Professor John Gunn on violence and psychosis (30 June, p 1945 and 7 July, p 9) revealing and disturbing. Working as a police surgeon, I have been told by police officers (and this has sometimes been confirmed by personal observation) that at times it has proved impossible for them to secure admission into a mental hospital of a prisoner brought into a police station who was considered to be emotionally disturbed. Quite often the only way that the police felt that they could deal with the problem was to charge such a prisoner and get him before a magistrate, who could then remand him for the usual psychiatric reports.

The finding of such emotionally disturbed prisoners on remand in prison is then due not so much to the "tendency on the part of the police to view mentally ill men as more dangerous than their more psychiatrically normal peers," but to the admission policies of a particular psychiatric team or mental hospital.

$S$ E Josse

Brownlow Medical Centre,
London N11 2BD

\section{Treatment of oesophageal cancer}

SIR,-The audit by $\mathrm{Mr}$ Richard Earlam of regional practice in the management of oesophageal carcinoma (23 June, p 1892) comes at a time when important advances are occurring in the palliation of this difficult problem. These have included accurate staging for operability, ${ }^{1}$ pertubation, ${ }^{2}$ and radiotherapy. ${ }^{3}$ We would like to contrast the experience in north east Thames region with ours in a specialist unit in a medium sized district.

Over three and a half years 66 patients were recruited from an estimated catchment population of 232000 . This was achieved by a combination of orthodox outpatient referrals and a GP open access endoscopy service. These patients were all admitted to hospital for management of nutritional problems or staging by fibreoptic endoscopy, isotope liver scan, and laparoscopy. One quarter $(27 \%)$ were referred subsequently for surgery, which in $60 \%$ was radical. Palliation was achieved in the remainder by endoscopic pertubation $(27 / 66 ; 41 \%)$ or radiotherapy, chemotherapy, or both $(32 \%)$. There were no early deaths after surgery. Good or excellent swallowing was achieved by one or other method in $80 \%$ of patients. One year survival rates in patients treated with surgery were $60 \%$, in patients treated with pertubation $25 \%$, and patients treated with radiotherapy $10 \%$.

These results compare well with those of $\mathrm{Mr}$ Earlam's survey. They show, we believe, the virtues of the specialist approach to diagnosis and nutritional management, combined with accurate staging and appropriate referral to experienced surgeons. The treatment of oesophageal carcinoma in our area has also been facilitated by trained endoscopy nurses 
educating patients who have been pertubated. Finally, the cooperation of interested local general practitioners, whose skills in domiciliary terminal care are keenly appreciated, is fundamental. That teamwork and adequate endoscopic resources are essential in treating this challenging malignancy is obvious from our results and those of other gastroenterologists.

\section{VISWANATH}

A N HAMLYN

Dudley Hospitals
Gastrointestinal Unit,
Wordsley Hospital,
Stourbridge,
West Midlands

' Gross E, Bancewicz J, Ingram G. Assessment of gastric cancer by laparoscopy. $\mathrm{Br}$ Med $\mathcal{\mathcal { F }} 1984$;288 gastri.

${ }^{2}$ Ogilvie AL, Dronsfield MW, Ferguson R, Atkinson Mlasms at fibreoptic endoscopy. Gut 1982;23:
1060-7.

${ }^{3}$ Pearson JG. The present status and future potential of radiotherapy in the management of oesophagea cancer. Cancer 1977;39:882-90.

SIR,-The operative mortality of $30 \%$ estimated by $\mathrm{Mr}$ Richard Earlam (23 June, p 1892) is, I believe, a true reflection of the work of the occasional oesophagectomist. It is a measure of the failure in Britain to train surgeons in this special problem and to organise the care of these patients in a hospital that has a fully trained surgical team and the ancillary assistance which these patients require.

As pointed out by Miss Mary Shepherd (14 July, p 114), a mortality of $33 \%$ is unacceptable and is vastly greater than that obtained in centres of excellence. Published mortality figures may not reflect the true position, as is emphasised by Mr R M Kirk, ${ }^{1}$ but this theory is overcome by the work of Paris, who sent a questionnaire to 57 surgeons throughout the world who had special expertise in treating cancer of the oesophagus, asking for the mortality figures obtained in their units even though these figures had not been published. ${ }^{2}$ The results of this study, which was carried out in 1976, showed that the overall mortality was $18 \%$. This figure corresponds closely with the $14.3 \%$ recorded by Collis $(1971){ }^{3}$ the $14.4 \%$ recorded by Gavriliu (1976), ${ }^{4}$ and the $18 \%$ recorded by Jackson et al (1979). ${ }^{5}$ In a review of a personal series (to be published in October) the overall mortality in 478 cases was $10 \cdot 1 \%$. In this series only those unfit for anaesthesia or who had extensive metastases were refused operation. No case was turned down as a bad risk because of age or concomitant disease. In a similar series Mannell (1982), using the same techniques as used in the Darlington series, reduced the overall mortality still further to $9 \cdot 8 \% .{ }^{6}$

The extremely low mortality figures of $1.2 \%$ recorded by Akiyama and his colleagues ${ }^{7}$ (one death out of 81 cases) and of $1.3 \%$ by Henry Ellis $^{8}$ (three deaths in 149 cases) reflect the results obtained by highly skilled surgeons in highly selected cases. As such they are not comparable to the results recorded above.

The outstanding lessons to be learnt are that oesophageal surgery requires special individual personal training to selected surgeons and that the admission of cases of oesophagea carcinoma to centres of special skills should be encouraged if not organised. To attain these objectives the formation of an association of oesophageal surgeons is long overdue.

\section{K C MCKeOWN}

' Kirk RM. Double indemnity in oesophageal carcinoma? Br Med f 1983;286:582-3.

Paris F. Quoted by McKeown KC. In: Nyhus LM ed. New York: Appleton-Century-Crofts, 1980:264 Collis JL. Surgical treatment of carcinoma of the oesophagus and cardia. Br $\mathcal{F}$ Surg 1971;58:801. Gavriliu D. Aspects of oesophageal surgery. Chicago,
London: Year Book Medical Publishers, 1979. (Current problems in surgery 1979.)

Jackson JW, Cooper DKC, Guvendik L, Reece-Smith $\mathrm{H}$. The surgical management of malignant tumour of the oesophagus and cardia: a review of the results of 292 patients treated over a 15 year period (1961Manneli A Carcinoma of the oesopho

London: Year Book of the oesophagus. Chicago, (Current problems in surgery 1982.)

Akiyama $\mathrm{H}$, Miyaxoho $\mathrm{H}$, Tsurumaru $\mathrm{M}$, Hishimoto $\mathrm{C}$, Kawamura $\mathrm{H}$. Thoraco-abdominal a pproach for carcinoma of the oesophagus. Am I Surg 1979;137: 345-9.

${ }^{8}$ Ellis FH. Oesophagogastrectomy for carcinoma of the oesophagus and cardia ; current risks and results. In: Watson A, Celestin LR, eds. Disorders of the oesophagus. London: Pitman, 1984:193.

\section{Video as a teaching aid}

SIR,-We agree with Dr M Afzal Mir and others (7 July, p 31) that "videotape demonstrations can be as effective as personal teaching." Dr Mir's study was with medical students; as part of a Scottish national research project we have shown this medium to be effective in teaching other professional groups and patients. ${ }^{1}$

Forth Valley Health Board and Stirling University produced educational videos and evaluated their use in normal hospital, clinic, and surgery settings. A video showing urine glucose testing was shown to 11 diabetic patients. The patients then had to demonstrate the test, and their performance was scored objectively on a specially designed form. These patients' results were compared with those of 10 patients who had watched a nurse's demonstration, and there was no significant difference between the two groups. On another occasion 22 patients who regularly used a specific urine test were asked to demonstrate the test before and after viewing the video. Objective scoring of their performance showed a significant improvement $(\mathrm{p}<0.01)$ after viewing.

We then found that video was equal to a demonstration by a trained nurse in teaching new skills to patients, nurses, and doctors and was also effective in reinforcing partial knowledge previously acquired. Video was better than poster demonstration and written instruction.

A later investigation of 86 patients in general practice showed that patients were extremely positive to this medium: $85 \%$ wanted videos to be used more in hospitals and surgeries.

Patient education videos have now been made available for use in general hospitals and some health centres within the health board area. Although an extremely useful medium, videos are not always appropriate and professional back up should be available to answer patients' questions. The style of teaching technique used in the videos is important as this can greatly affect both the amount learnt and the motivation of the individual to apply the information he has retained. ${ }^{2} 3$

We should like to acknowledge the assistance of both patients and professional staff throughout this study and also the funding provided by the Scottish Health Education Group.

$S$ REITH

J L GRAHAM

C MCEWAN

K J FRASER

Forth Valley Health Board,

Stirling FK8 1DX
' McEwan C, Fraser KJ. Videorecorded programmes for patient education. In: Bateman EC, ed. Applied nutrition: 2 (Proceedings of $B D A$ study
1983). London: John Libbey (in press).

Baggaley J. Psychology of the TV image. Westmead, Hants: Gower 1980

Coldevin GO. Experimental research in television production techniques and presentation strategies; and current directions. Fournal of Educational Television and Other Media 1980;3:92-7.

SIR,-One aspect of the valuable study of $\mathrm{Dr}$ M Afzal Mir and others (7 July, p 31) merits further comment. Examiners used standardised scoring charts for rating clinical skills. Included in these skills was the examiner's "impression" of the student's "overall approach, style, performance and fluidity." Pioneered by Harden and Gleeson, ${ }^{1}$ structured practical examinations of this type have been shown to be valid, ${ }^{2}$ but there is evidence that the reliability of examiner rating is not satisfactory..$^{23}$ Also, such appraisal of physical examination performance may not necessarily reflect student ability to evaluate the patient's physical state." 5 (If the check list item "correct conclusion" in the study of Dr Afzal Mir and others refers to this ability it would be of interest to know whether individual student score on this item correlated with scores on items concerned with performance alone.)

Until the problem of marker reliability and the practical implications of a thorough and generally proficient observer rated performance are adequately resolved, in evaluating methods directed to the acquisition of diagnostic skills it is important to use tests that include measurements of the outcome as well as the process.

R F GLEDHILL

Department of Neurology,

Institute of Psychiatry,
London SE5 8AF

'Harden RM, Gleeson FA. Assessment of clinical competence using an objective structured clinical examination (OSCE). Med Educ 1979;13:41-54.

${ }^{2}$ Newble DI, Hoare J, Elmslie RG. The validity and reliability of a new examination of the clinical

46-52.
${ }^{3}$ Gledhill RF. Factors affecting the reliability of an objective structured clinical examination (OSCE) test in neurology. S Afr Med $\mathcal{F}$ (in press).

Feighter JW. Doy WB, Norman GR, Rand CA, Med Educ 1983;17:24-7.

Med Educ 1983;17:24-7.
${ }^{5}$ Gledhill RF. Evaluating clinical competence in students. Lancet $1983 ; \mathrm{i}: 595$.

\section{Uterine prolapse and urinary tract} obstruction

SIR,-I want to add a note of caution to Dr J B Young and others' lesson of the week on uterine prolapse and urinary tract obstructions (7 July, p 41). I did not think that this problem was considered unusual, having seen several cases while working in Nottingham. On one such occasion I was flushed with success having "cured" a woman's anuria by replacing the procidentia and fitting a ring pessary. I was then asked by sister if I would care to perform the same "miracle" on another old woman with anuria and uterine procidentia who had had abdominal surgery.

After discussion we decided that the anuria was almost certainly postrenal in cause, and the prolapse was replaced with slightly more difficulty than in the previous case due to tissue oedema. Sure enough, urine started to flow, and I left the ward content with my two "miracles" for that day.

Later that evening while rehydrating ourselves after the day's trials and tribulations, we met the intensive care staff and were informed that the second woman had been relieved of the 